\title{
Using Dollarized Countries to Analyze the Effects of US Monetary Policy Shocks*
}

\author{
Tim Willems ${ }^{\dagger}$
}

January 19, 2011

\begin{abstract}
Identifying monetary policy shocks is difficult. Therefore, instead of trying to do this perfectly, this paper exploits a natural setting that reduces the consequences of shock misidentification. It does so by inferring from the responses of variables in dollarized countries. They import US monetary policy just as genuine US states do, but have the advantage that non-monetary US shocks are not imported perfectly. Consequently, this setting reduces the role played by any non-monetary US shocks, while leaving the effects of the true monetary shocks unaffected. Results suggest that prices fall after monetary contractions; output does not show a clear response.

JEL-classification: E52; E31; C32

Key words: Monetary policy effects; Price puzzle; Structural VARs; Identification; Block exogeneity
\end{abstract}

\section{Introduction}

Despite the fact that monetary instruments are widely used as policy tools, there is only little agreement on their actual economic impact. Although numerous scholars have analyzed the effects of monetary policy shocks on output and prices by

${ }^{*}$ I thank Hal Cole, Martin Eichenbaum, Wouter den Haan, Alexander Kriwoluzky, Bartosz Maćkowiak, Arturo Ormeño, Vincent Sterk, Christian Stoltenberg and Sweder van Wijnbergen for useful comments and discussions. Gunnar Poppe Yanez provided excellent research assistance. Any errors are of course mine.

${ }^{\dagger}$ Department of Economics, University of Amsterdam, Roetersstraat 11, 1018 WB Amsterdam, The Netherlands. E-mail: t.willems@uva.nl. 
estimating vector autoregressions ("VARs") and subsequently looking at the accompanying impulse response functions ("IRFs"), the outcomes of these exercises have been rather puzzling. In particular, many studies find that prices increase after a contractionary monetary shock, which goes against the predictions of most standard macroeconomic theories (such as the New Keynesian one). Even though this price response can be rationalized through the working capital channel, ${ }^{1}$ it is generally referred to as "the price puzzle".

Currently, there are three popular explanations for the positive response of prices to an interest rate increase. First, some have argued that the working capital channel indeed is important and that prices really go up after a monetary tightening. If this is true, then the price puzzle is not a puzzle and incorporation of the cost channel into standard macroeconomic models seems desirable. ${ }^{2}$

Second, it has been argued that the price puzzle reflects the fact that the estimated VAR contains less information than available to the monetary authority (Sims, 1992). The idea is that when the monetary authority knows that inflation is about to arrive and contracts in response, prices will still rise, but by less than they would have without the contraction. Sims (1992) tries to correct for this by introducing a commodity price index in the VAR and shows that this decreases the puzzle. This result is however not very robust. Hanson (2004) for example fails to find a correlation between the ability of variables to forecast inflation and the ability to resolve the price puzzle. Moreover, he shows that including commodity prices in the VAR does not work for an early sample period, running from 1959 to 1979. His findings thus suggest that either the price puzzle is not a puzzle (it is just the working capital channel at work), or that there is a different problem.

In this light, it might also be the case that the necessary identifying restrictions are not met in practice and play a distorting role. A popular way to identify VARs is to assume that some variables do not respond to certain shocks within the period. But as for example argued in Canova and Pina (2005), these inertial restrictions may not hold in reality as a result of which shocks are misidentified and resulting IRFs (such as the one for the price level) can be of the wrong sign.

This paper focuses at this last problem. Hereby, it tries to shed light on the

\footnotetext{
${ }^{1}$ With a working capital channel in place, firms need to borrow funds in order to be able to pay for their production factors. Consequently, the interest rate becomes a determinant of real marginal costs. Cf. Van Wijnbergen (1983), who obtained the price puzzle - avant la lettre - in such a model.

${ }^{2}$ This development has actually started already: Barth and Ramey (2001, p. 199-200) state that "cost-side theories of monetary policy transmission deserve more serious consideration". Christiano, Eichenbaum and Evans (2005) did this and added the working capital channel to their model to replicate the price puzzle. Ravenna and Walsh (2006) discuss how a working capital channel affects the optimal monetary policy.
} 
question whether economic theory should take the price puzzle seriously, or whether it is just an artifact of distorting identifying assumptions. As I acknowledge the potential of the working capital channel to explain the price puzzle, I do not take a prior position on what the price effects of monetary policy shocks should be. This distinguishes my approach from the sign restriction procedure employed by for example Uhlig (2005). That approach dismisses the cost channel and identifies a contractionary monetary shock as a shock that (among other things) does not increase the price level.

To circumvent the use of sign restrictions, this paper takes advantage of a convenient natural setting that has not been exploited before: it uses output and price data from dollarized countries (all located in Latin America). Previous studies have always looked at the responses of US variables to analyze the effects of US monetary shocks. That approach, however, does not use all available information. In particular, it neglects the fact that we can also look at the responses of variables in dollarized countries. Economically speaking, they are not so different from genuine US states as they import US monetary policy shocks just as normal US states do. After all, dollarized countries also use the US dollar as legal tender (just like Idaho or any other US state does), without having the possibility to deviate from US monetary policy, as there is no local currency to de- or revalue.

Taking this geographical detour has two advantages. First, the econometric restrictions that follow from this setting, enable one to analyze the effects of US monetary policy shocks in the client economies, without imposing inertial or sign restrictions on the variables of interest.

Second, basing conclusions upon the responses of variables in dollarized countries makes this paper's findings less prone to the major concern any structural VAR exercise has to face: misidentification of the US monetary shock. This is the case because the dollarized countries that are going to be considered (Ecuador, El Salvador and Panama) are only imperfectly integrated with the US economy. In particular, the economies of Ecuador and El Salvador are relatively closed, ${ }^{3}$ which is probably a result of the fact that these countries were rather late with decreasing their trade barriers ( $c f$. Sachs and Warner (1995)). In addition, to the extent that these economies do engage in international trade, most of their exports (imports) also go to (come from) non-US states. ${ }^{4}$ Consequently, non-monetary US shocks can be expected to

\footnotetext{
${ }^{3}$ As reported by the CIA World Factbook, the ratio of exports (imports) to GDP equaled 0.250 (0.249) for Ecuador in 2009. For El Salvador, these numbers are 0.183 and 0.318 and for Panama they equal 0.441 and 0.523 . To compare: for a textbook open economy, such as Singapore, these ratios are 1.550 and 1.358, while the corresponding US numbers equal 0.073 and 0.110 .

${ }^{4}$ According to the Factbook, 66 percent of Ecuadorian exports (73 percent of their imports)
} 
produce only rather limited output- and price fluctuations in these countries - especially at short horizons. After all, to the extent that these shocks do spill over, this is likely to happen after some time delay only. ${ }^{5}$

Lindenberg and Westermann (2010) actually investigated this issue empirically and show that Latin America does not seem to share its business cycle with the US. ${ }^{6}$ This suggests that these cycles are not driven by the same shocks (or that the shocks are only transmitted with a delay). By looking at the already dollarized economies of El Salvador and Panama, they are also able to reject the hypothesis that business cycle synchronization is "endogenous", as they find that the business cycles of these countries do not show a bigger comovement with the US cycle than those of nondollarized countries. In line with this, Canova (2005) even finds that non-monetary US shocks do not tend to produce significant output or price fluctuations in Latin America at all.

So all this suggests that even if the identified "monetary policy shock" includes some non-monetary US components, the consequences of this mistake are contained in the present setting as the transmission of these non-monetary US disturbances to Latin America is not instantaneous and perfect. Although this approach is certainly not flawless (for that one needs to find a dollarized economy that is fully shielded from non-monetary US shocks, that is: one needs to find a dollarized economy on a different planet!), it works at least a bit like an ideal filter, as it reduces (or at the very minimum: delays) the effects of any non-monetary US shocks on client country variables, while leaving the effects of the true monetary shocks unaffected.

The results of this exercise are univocal: when one analyzes the effects of a contractionary US monetary shock through dollarized economies, prices in the client countries fall quickly and significantly (both in a statistical and in an economic sense) - so the price puzzle disappears. Quantitatively, the data suggest that prices

went to (came from) other countries than the US in 2009. For El Salvador, these numbers are 56 percent for exports and 70 percent for imports. Finally, Panama exported 82 percent (imported 88 percent) of their total to (from) non-US trading partners.

${ }^{5}$ Non-monetary shocks are typically transmitted through the time-consuming trade channel, as a result of which they need a while to arrive at a different region. Monetary shocks, on the other hand, are transmitted fully and instantaneously through financial markets. This observation has a long standing tradition in international economics, going back to at least Dornbusch (1976).

${ }^{6}$ In particular, they report that the correlation in growth rates between the US and El Salvador (Panama) equals only 0.234 (0.119) (Ecuador is not included in their study). To compare: for Canada and Mexico the correlations with US growth rates equal 0.77 and 0.73 , respectively. A similar result is reported by Alesina, Barro and Tenreyro (2002): they also show that output comovement between the US and the dollarized countries under consideration is actually not that high. (The comovement of price levels is high on the other hand, but that is to be expected under (semi-)dollarization.) 
in the economies considered were pretty flexible over the sample period. Output does not show a clear response, so monetary neutrality cannot be rejected.

\section{$2 \quad$ Identifying monetary policy shocks}

To identify structural shocks, one has to start with the estimation of a reduced form VAR with $p$ lags for a vector of variables $Z_{t}$, which is of size $(k \times 1):^{7}$

$$
Z_{t}=\sum_{i=1}^{p} B_{i} Z_{t-i}+u_{t},
$$

with $Z_{t}=\left(X_{1, t}^{\prime}, R_{t}, X_{2, t}^{\prime}\right)^{\prime}$. Here, $X_{1, t}^{\prime}$ is a $\left(k_{1} \times 1\right)$-vector whose contemporaneous values are assumed to be in the information set of the central bank. $X_{2, t}^{\prime}$ (of dimension $\left.\left(k_{2} \times 1\right)\right)$ on the other hand contains those variables whose contemporaneous values are not in the information set of the monetary authority (its lags are though).

The $B$-matrices in equation (1) can be estimated by OLS, after which one can calculate the reduced form errors $u_{t}$ with $\mathbb{E} u_{t} u_{t}^{\prime}=\Sigma$. However, there is nothing that ensures that the residuals are contemporaneously uncorrelated, as a result of which we cannot give them a structural economic interpretation. We can do this once we have transformed the variance-covariance matrix of the residuals into a diagonal one.

This can be achieved by premultiplying the reduced form (equation (1)) with $A_{0}$, a $(k \times k)$-matrix that captures the contemporaneous relations between the variables in $Z_{t}$. This gives us the structural form representation of (1):

$$
A_{0} Z_{t}=\sum_{i=1}^{p} A_{i} Z_{t-i}+\varepsilon_{t}
$$

where $A_{i}=A_{0} B_{i}, i=1, \ldots, p$, and $\varepsilon_{t}=A_{0} u_{t} . \varepsilon_{t}$ is a $(k \times 1)$-vector of structural (that is: uncorrelated) shocks with $\mathbb{E} \varepsilon_{t} \varepsilon_{t}^{\prime}=I$. It then follows that $\Sigma=A_{0}^{-1}\left(A_{0}^{-1}\right)^{\prime}$.

As shown in CEE (1999), it is possible to identify the monetary policy shock by assuming that $A_{0}$ has the following, lower-triangular structure:

$$
A_{0}=\left[\begin{array}{ccc}
A_{0,11} & \mathbf{0} & \mathbf{0} \\
\left(k_{1} \times k_{1}\right) & \left(k_{1} \times 1\right) & \left(k_{1} \times k_{2}\right) \\
A_{0,21} & A_{0,22} & \mathbf{0} \\
\left(1 \times k_{1}\right) & (1 \times 1) & \left(1 \times k_{2}\right) \\
A_{0,31} & A_{0,32} & A_{0,33} \\
\left(k_{2} \times k_{1}\right) & \left(k_{2} \times 1\right) & \left(k_{2} \times k_{2}\right)
\end{array}\right]
$$

\footnotetext{
${ }^{7}$ This section draws upon Christiano, Eichenbaum and Evans (1999, henceforth CEE).
} 
A matrix that has this form, is the Choleski decomposition of $\Sigma$.

Next to the fact that the structure imposed by (3) is consistent with the informational assumption made about the central bank before, ${ }^{8}$ it also implies that the monetary policy instrument $R_{t}$ (taken to be the federal funds rate, as in Bernanke and Blinder (1992)) has no contemporaneous impact on the variables in $X_{1, t}:{ }^{9}$ it can only affect these variables with a lag. Any variables in $X_{2, t}$ on the other hand, can be affected within the period.

A popular way to identify monetary policy shocks, employed by CEE (1999), is to assume that $X_{1, t}$ includes data on output and prices, while the $X_{2, t}$-vector is either assumed to be empty or contains data on monetary aggregates. Economically, this implies that the monetary authority is able to react to changes in output and prices within the period, while the output and price effects of monetary shocks can only show up after one period.

Alternatively, one can also go down the lines of Sims and Zha (2006) and assume the opposite by allowing for impact effects of monetary shocks on output and prices, but assuming that the contemporaneous values of output and prices are not in the Fed's information set. This assumption is motivated by the fact that gathering and processing the necessary data takes time, as a result of which monetary policy may not be able to respond to changes in these variables within the period.

The degree of realism of both restrictions can however be questioned: the majority of existing theoretical models imply that output and prices already respond on impact of a shock (which the CEE-scheme does not allow for), while the availability of now- and forecasts makes the Sims-Zha approach debatable. ${ }^{10}$ As Canova and Pina (2005) show, the imposition of both of these type of restrictions may lead to shock misidentification, as a result of which IRF coefficients can get the wrong sign (which may remind some of the price puzzle).

Summarizing, there thus seems to exist a trade-off: on the one hand, one could use the CEE-scheme, which gives the monetary authority the most realistic information set, but this comes at the cost of having to assume that other variables in the VAR cannot respond to these shocks within the period. On the other hand, one could also follow the Sims-Zha approach (which does allow for impact effects of monetary shocks) but this comes at the expense of having to restrict the monetary authority's information set.

\footnotetext{
${ }^{8}$ The fact that $A_{0,23}$ only contains zeros implies that the variables in $X_{2, t}$ are not in the Fed's information set.

${ }^{9}$ This follows from the fact that $A_{0,12}$ only contains zeros.

${ }^{10}$ Sims and Zha (2006) themselves already stated that their identifying restriction "can never be more than an interesting working hypothesis" for this reason (p. 249).
} 
As will be argued in the following section, dollarized countries can offer a solution to this conundrum by essentially allowing us to combine the best of both approaches.

\section{Dollarized countries to the rescue}

To address the issues set out in the previous section, this paper does not look at the responses of US output and US prices to federal funds rate shocks (henceforth referred to as $Y^{U S}, P^{U S}$ and $R^{U S}$, respectively), but uses their counterparts from dollarized countries instead $\left(Y^{D}\right.$ and $\left.P^{D}\right)$. This approach has two advantages. First, it allows us to combine the two dominant existing approaches in a convenient way: we can identify US monetary shocks in the US block of the system (with the contemporaneous values of $Y^{U S}$ and $P^{U S}$ in the Fed's information set), while we can analyze the impact of these shocks by looking at the responses of output and prices in the dollarized economies, without imposing inertial or sign restrictions on these variables of interest.

Second, inferring from responses of dollarized country variables makes the procedure less vulnerable to misidentification of the monetary shock. As Canova (2005) reports, the transmission of non-monetary US shocks to Latin American countries is far from perfect. ${ }^{11}$ This implies that if the identified "monetary policy shock" contains a non-monetary component, the latter does not survive the transmission process undamaged and, ideally, only the effects of the true monetary shock remain.

Related to this, the exploited setting also has the ability to "convert" endogenous policy responses to non-monetary disturbances, into monetary policy shocks. To see this, consider the following example: ${ }^{12}$ say that the US is hit by a non-monetary shock, in response to which the Fed immediately raises the interest rate. At this stage, US variables are moved by both the direct effect of the non-monetary shock, as well as by an indirect effect, being the endogenous response of the monetary authority. But as this response took place within the period, the sum of the two effects will look like a monetary policy shock to the observer in standard VAR-specifications, which is wrong as there never was a monetary shock in reality (only the endogenous response to the non-monetary shock). However, output and prices in dollarized countries are unlikely to be moved within the period by the non-monetary US shock. Hence, the direct effect gets killed in the transmission process and the full, unexpected interest rate increase is a true monetary policy shock from the perspective of the dollarized

\footnotetext{
${ }^{11}$ Canova's (2005) analysis includes both Ecuador and Panama. The other countries included in his study are Argentina, Brazil, Chile, Mexico, Peru and Uruguay.

${ }^{12}$ I owe this example to Wouter den Haan.
} 
countries. So where standard VAR exercises need random variations in the monetary policy instrument, the current setting is able to provide us with monetary shocks (through the eyes of the client countries) even if the Fed only responds in a perfectly predictable way to unpredictable US developments (under the proviso that the latter are not immediately transmitted to the dollarized economies).

As noted before, I am aware that the client economies considered are probably not fully insulated from non-monetary US shocks (especially at longer horizons), and that next to those, there may also be aggregate world-wide shocks affecting both the client countries and the US simultaneously. ${ }^{13}$ It seems reasonable to assume, however, that the exploited setting at least reduces the consequences of shock misidentification somewhat (a conjecture that will be investigated in greater detail in Section 5).

When estimating the required system, this paper uses the fact that the US economy can be taken to be exogenous to the dollarized economies (as the latter are all small). In particular, one can make use of the fact that the Fed does not pay any attention to economic conditions in these client countries when designing its monetary policy. Building upon Lastrapes (2005), the remainder of this section sets out an estimation and identification strategy that exploits this convenient natural setting.

\subsection{Estimation}

Let $Q_{t}$ be a vector stochastic process that is assumed to be generated by: ${ }^{14}$

$$
C_{0} Q_{t}=\sum_{i=1}^{q} C_{i} Q_{t-i}+\epsilon_{t}
$$

Here $\epsilon_{t}$ is a normalized, white noise vector process such that $\mathbb{E} \epsilon_{t} \epsilon_{t}^{\prime}=I$. The corresponding reduced form of this model is:

$$
Q_{t}=\sum_{i=1}^{q} F_{i} Q_{t-i}+v_{t},
$$

with $F_{i}=C_{0}^{-1} C_{i}, i=1, \ldots, q, v_{t}=C_{0}^{-1} \epsilon_{t}$ and where $\mathbb{E} v_{t} v_{t}^{\prime}=\Omega=C_{0}^{-1}\left(C_{0}^{-1}\right)^{\prime}$.

\footnotetext{
${ }^{13}$ Given the evidence presented in Gabaix (forthcoming), who shows that many "aggregate US shocks" are actually idiosyncratic shocks to large US firms, one can however question how common an "aggregate world-wide shock" is.

${ }^{14}$ To simplify notation, I suppress the constant and linear time trend that are also included in the analysis. Since the data on dollarized countries are not seasonally adjusted, I also include quarterly dummies in the client country block to remove any possible seasonality in these series.
} 
In estimating the reduced form, I impose two over-identifying restrictions. First, regarding the absorption of shocks, I assume that the correlation between output and prices in the client countries is solely due to their joint dependence on the US variables. ${ }^{15}$ This makes it possible to estimate the system efficiently by OLS (see Lastrapes (2005)). As one could debate the reasonableness of this assumption, I show in the Appendix that the results are robust to dropping this restriction (in which case one must estimate the system by seemingly unrelated regressions).

Second, with respect to the emission of shocks from dollarized countries, I assume that the US variables are block exogenous with respect to the variables in the dollarized countries. That is: whatever happens in the client country, is assumed to have no impact on the US economy, as the former is too small to affect the latter. ${ }^{16}$

Econometrically, these assumptions amount to the following: organize $Q_{t}$ such that $Q_{t}=\left(Q_{t}^{D}, Q_{t}^{U S}\right)^{\prime}$, where $Q_{t}^{D}=\left(Y_{t}^{D}, P_{t}^{D}\right)^{\prime}$ and $Q_{t}^{U S}=\left(Y_{t}^{U S}, P_{t}^{U S}, R_{t}^{U S}\right)^{\prime} .{ }^{17}$ Block exogeneity of $Q_{t}^{U S}$ with respect to $Q_{t}^{D}$ then implies that all $C$-matrices will be upper-triangular. That is:

$$
C_{i}=\left(\begin{array}{cc}
C_{i, 11} & C_{i, 12} \\
\mathbf{0} & C_{i, 22}
\end{array}\right), i=0, \ldots, q
$$

The assumption regarding the absorption of shocks implies that $C_{i, 11}$ is diagonal. Partitioning the VAR into a dollarized country- and a US-block gives:

$$
\left(\begin{array}{c}
Q_{t}^{D} \\
Q_{t}^{U S}
\end{array}\right)=\sum_{i=1}^{q}\left(\begin{array}{cc}
F_{i, 11} & F_{i, 12} \\
\mathbf{0} & F_{i, 22}
\end{array}\right)\left(\begin{array}{c}
Q_{t-i}^{D} \\
Q_{t-i}^{U S}
\end{array}\right)+\left(\begin{array}{c}
v_{1, t} \\
v_{2, t}
\end{array}\right)
$$

Equivalently, the associated variance-covariance matrix $\Omega$ can be partitioned into:

$$
\Omega=\left(\begin{array}{ll}
\Omega_{11} & \Omega_{12} \\
\Omega_{12}^{\prime} & \Omega_{22}
\end{array}\right)
$$

As set out in Hamilton (1994, pp. 309-313), block exogeneity of $Q_{t}^{U S}$ with respect to $Q_{t}^{D}$ implies that (7) can be re-parameterized and separated into two independent parts, least squares estimation of which is fully efficient:

\footnotetext{
${ }^{15}$ That is: the equation for $Y^{D}$ (in casu $P^{D}$ ) only contains its own lags (and lags of $Y^{U S}, P^{U S}$ and $R^{U S}$, of course). So lagged values of $P^{D}$ do not enter the equation for $Y^{D}$ and vice versa.

${ }^{16}$ See, among others, Cushman and Zha (1997) for an earlier study that imposes such a block exogeneity restriction on small economies.

${ }^{17}$ Note that the empirical results that are to follow are invariant to the ordering of the output and price variables within each block, as I am only going to look at a shock to $R_{t}^{U S}$.
} 


$$
\begin{aligned}
Q_{t}^{D} & =\sum_{i=1}^{q} F_{i, 11} Q_{t-i}^{D}+\sum_{i=0}^{q} G_{i} Q_{t-i}^{U S}+e_{t} \\
Q_{t}^{U S} & =\sum_{i=1}^{q} F_{i, 22} Q_{t-i}^{U S}+v_{2, t},
\end{aligned}
$$

where:

$$
\begin{aligned}
G_{0} & =\Omega_{12} \Omega_{22}^{-1} \\
G_{i} & =F_{i, 12}-G_{0} F_{i, 22} \Leftrightarrow F_{i, 12}=G_{i}+G_{0} F_{i, 22}, i=1, \ldots, q \\
\mathbb{E} e_{t} e_{t}^{\prime} & =\Omega_{11}-\Omega_{12} \Omega_{22}^{-1} \Omega_{12}^{\prime}
\end{aligned}
$$

\subsection{Identification}

Once the system is estimated, one still has to identify the structural form (given by equation (4)). The vector moving average representation of the latter is:

$$
\begin{aligned}
Q_{t} & =\left(C_{0}-C_{1} L-\ldots-C_{p} L^{p}\right)^{-1} \epsilon_{t} \\
& =\left(H_{0}+H_{1} L+H_{2} L^{2}+\ldots\right) \epsilon_{t}
\end{aligned}
$$

Equivalently, the vector moving average representation of the reduced form (equation (5)) equals:

$$
\begin{aligned}
Q_{t} & =\left(I-F_{1} L-\ldots-F_{p} L^{p}\right)^{-1} v_{t} \\
& =\left(I+J_{1} L+J_{2} L^{2}+\ldots\right) v_{t}
\end{aligned}
$$

The goal now is to identify the $H$-matrices in equation (8), as these represent the system's impulse response functions $\left(H_{k}=\frac{\partial Q_{t+k}}{\partial \epsilon_{t}}\right)$. This can be done as follows.

Using that $v_{t}=C_{0}^{-1} \epsilon_{t}$ in equation (9) and comparing with (8) shows us that:

$$
\begin{aligned}
& H_{0}=C_{0}^{-1} \\
& H_{k}=J_{k} H_{0}, \quad k=1,2, \ldots
\end{aligned}
$$

By Hamilton (1994,p. 260) the solution to the inverted lag polynomial in (9) is: 


$$
\begin{aligned}
J_{0} & =I \\
J_{k} & =F_{1} J_{k-1}+\ldots+F_{p} J_{k-p}, \quad k=1,2, \ldots
\end{aligned}
$$

Moreover, given the imposed restrictions, we know that $H_{0,11}=C_{0,11}^{-1}$ and that $H_{0,21}=\mathbf{0}$. Through equation (10) one then obtains that $\Omega=H_{0} H_{0}^{\prime}$. Partitioning this matrix as before (and using that $H_{0,21}=\mathbf{0}$ ) yields:

$$
\left(\begin{array}{ll}
\Omega_{11} & \Omega_{12} \\
\Omega_{12}^{\prime} & \Omega_{22}
\end{array}\right)=\left(\begin{array}{cc}
H_{0,11} H_{0,11}^{\prime}+H_{0,12} H_{0,12}^{\prime} & H_{0,12} H_{0,22}^{\prime} \\
H_{0,22} H_{0,12}^{\prime} & H_{0,22} H_{0,22}^{\prime}
\end{array}\right)
$$

From (14), one can fully identify $H_{0}$ - and hence $H_{k}$ by using (11)-(13). Note that block exogeneity of $Q^{U S}$ implies that $H_{0,22}$ (which is where the US monetary policy shock lives) can be identified in isolation from the $Q^{D}$ block. Consequently, one can copy the attractive feature of the CEE-approach and allow for contemporaneous values of US variables in the Fed's information set by assuming that $H_{0,22}$ is lower triangular. However, as set out in Section 2, this approach does not allow for a contemporaneous impact of US monetary policy shocks on US prices and output, which is hard to defend in reality. But this is where the dollarized countries come in handy: because the Fed does not pay any attention to conditions in these countries when designing its monetary policy, there is no need for an inertial assumption here. Consequently, we can just feed the US monetary policy shock (fully located within the US block of the system) through the estimated system for the dollarized economy, while allowing for impact responses of any sign on output and prices in the latter.

However, this is still no guarantee that the true US monetary policy shock is identified correctly. But as argued before, the fact that the dollarized countries considered are only imperfectly integrated with the US economy, reduces the role played by any included non-monetary disturbances, which makes the route taken by this paper less prone to misidentification of the monetary shock in the US block of the system.

\section{What are the effects of monetary policy shocks?}

By now, we are in the position to analyze the effects of US monetary shocks on output and prices in dollarized economies. Quarterly output and price data are available for three of the largest dollarized countries: Ecuador (dollarized since 2000q1), El 
Salvador (dollarized since 2001q1) ${ }^{18}$ and Panama (dollarized since 1904, data available since 1996q1). For these countries, the left panels of all figures that are to follow display the IRFs of output and prices to a one standard deviation, contractionary US monetary shock. Note that these IRFs are obtained without imposing any restrictions on these variables. For comparison purposes, the right panel of each figure displays the IRFs of US prices and output to the same shock - a procedure that does need to impose a zero response on impact under the current identification scheme.

Following Bernanke and Mihov (1998), I use data on the implicit GDP deflator and real GDP as proxies for US prices and output, respectively. The federal funds rate is taken to be the monetary policy instrument. All US data are from the St. Louis Fed website. For the dollarized economies the GDP deflator is not available and the CPI (taken from the IMF's IFS database) is used instead. ${ }^{19}$ Data on real GDP is obtained from the central banks of Ecuador and El Salvador and from the Instituto Nacional de Estadística y Censo for Panama. All series (except the federal funds rate) are logged before they enter the VAR.

Results are based upon a VAR(2), where the lag-length was selected by Schwarz's Information Criterion. The reported 95 percent confidence bands are obtained via a Monte Carlo procedure (with 5,000 replications), in which artificial data was generated by bootstrapping the estimated residuals. As shown in the Appendix, results are robust to dropping the time trend and to adding M2 or a commodity price index to the VAR.

Ecuador Fig. 1 shows the result of this exercise for Ecuador, where the VAR was estimated on data running from 2000q1 to 2010q3. Its right panel confirms the finding of many earlier studies in this literature: following a monetary tightening, the US price level increases significantly in a very persistent way, which is hard to reconcile with existing theories..$^{20}$ In addition, US output goes up as well, so one

\footnotetext{
${ }^{18}$ Prior to official dollarization in 2000 , Ecuador was already effectively dollarized as its residents had started to use the US dollar for daily transactions in the mid-1990s and made increasing use of US dollar denominated loans and deposits since then (Beckerman, 2001). The former El Salvadorian currency (the colón) had already been pegged to the US dollar in 1993. So in practice both Ecuador and El Salvador had already been importing US monetary policy for some years when they dollarized officially in the early 2000s.

${ }^{19}$ This only strengthens this paper's finding that the price puzzle disappears once one analyzes the effects of monetary shocks through dollarized countries, as Hanson (2004, p. 1390) reports that the price puzzle is most severe when the CPI is used to measure the price level.

${ }^{20}$ As noted before, the price puzzle can be rationalized through the working capital channel, but this channel only predicts a short-lived increase in the price level after a contractionary shock, which is inconsistent with the picture shown here.
} 
could also speak of an "output puzzle" here.

But as shown in Canova and Pina (2005), these puzzling results may just be due to shock misidentification - caused by the fact that the imposed zero impact restrictions, necessary to obtain these IRFs, are not met in practice.

As set out before, including data from a dollarized country allows us to analyze the effects of this shock without imposing the zero response on impact, while it also helps to filter out the effects of any non-monetary elements of the identified shock. The results of this exercise are shown in the left panel of Fig. 1.
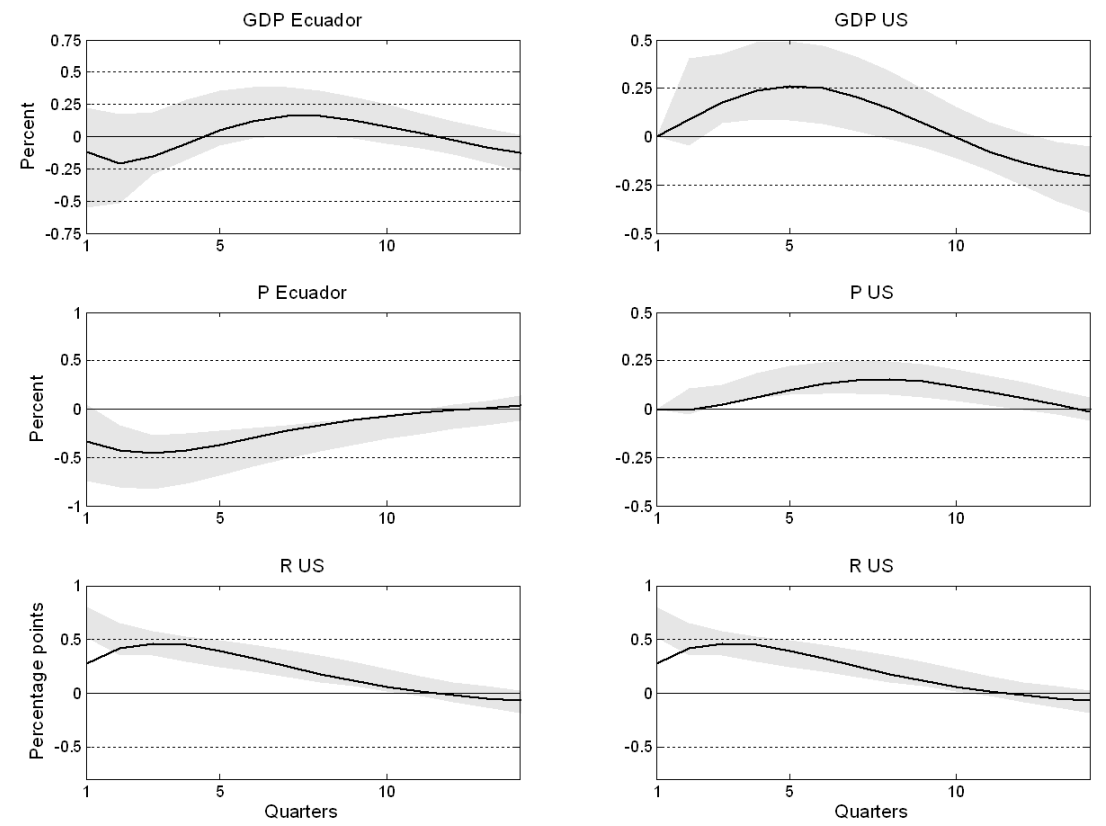

Figure 1: IRFs to a one standard deviation contractionary monetary policy shock for Ecuador and the US

Three things are to be noted about this. First, the puzzling price response of the standard approach is now reversed: the Ecuadorian price level falls quickly and significantly after a monetary contraction. As the shock fades away, prices increase again - just as most theories would predict. Second, although output does not move significantly, the point estimate indicates that it is depressed for about a year following the contraction. Finally, observe that the negative response of prices is quite large: after three quarters, prices have for example already fallen by about 0.45 percent. This suggests that prices were rather flexible in Ecuador over the 
sample period, which might explain why output does not show a clear and significant response. $^{21}$

El Salvador Fig. 2 contains the results of the same exercise, now applied to El Salvador (in which case the dataset runs from 2001q1 to 2010q3).
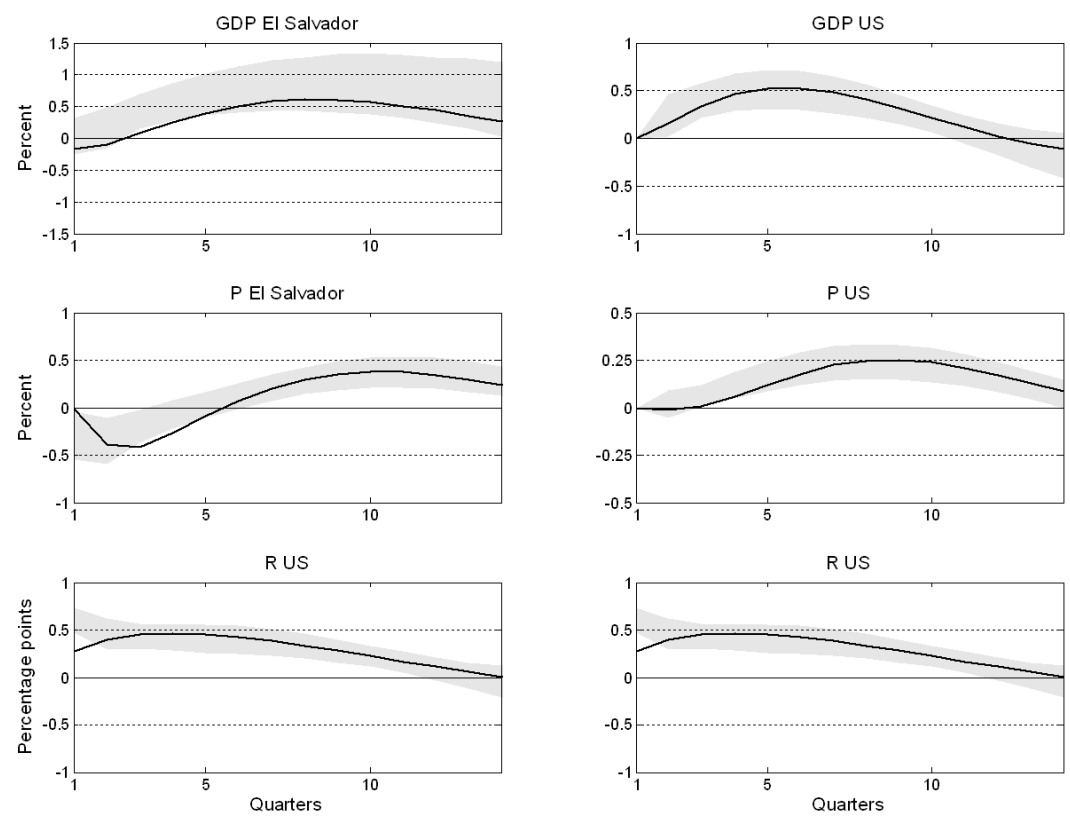

Figure 2: IRFs to a one standard deviation contractionary monetary policy shock for El Salvador and the US

The right panel again shows the puzzling picture that emerges for the US variables, where both prices and output increase after a monetary tightening. However, if one looks at the IRFs of the dollarized country, one concludes that prices fall after a contractionary monetary shock. Although GDP is depressed for the first two quarters, it goes up afterwards and even shows an output puzzle at longer horizons. ${ }^{22}$

\footnotetext{
${ }^{21}$ To get an idea of the degree of price stickiness reported in other VAR-studies: CEE (1999) find that prices stay virtually unchanged for the first 6 quarters after the shock, after which it takes prices about another 10 quarters to fall by 0.5 percent.

${ }^{22}$ In this respect, one should however keep in mind that this paper's procedure is less suited for analyzing the responses at longer horizons, as part of the possibly included non-monetary US shocks might have spilled over to the client countries by then.
} 
The latter finding is not too different from the results in Uhlig (2005): he finds that there are quite a few "contractionary monetary shocks" (identified with sign restrictions on US prices and monetary variables) that do not lead to a subsequent fall in output, which leads him to conclude that "contractionary monetary policy shocks do not necessarily seem to have contractionary effects on real GDP" (p. 385) ${ }^{23}$

Panama The results of applying the procedure to Panama (estimated on data running from 1996q1 to 2010q3) are depicted in Fig. 3.
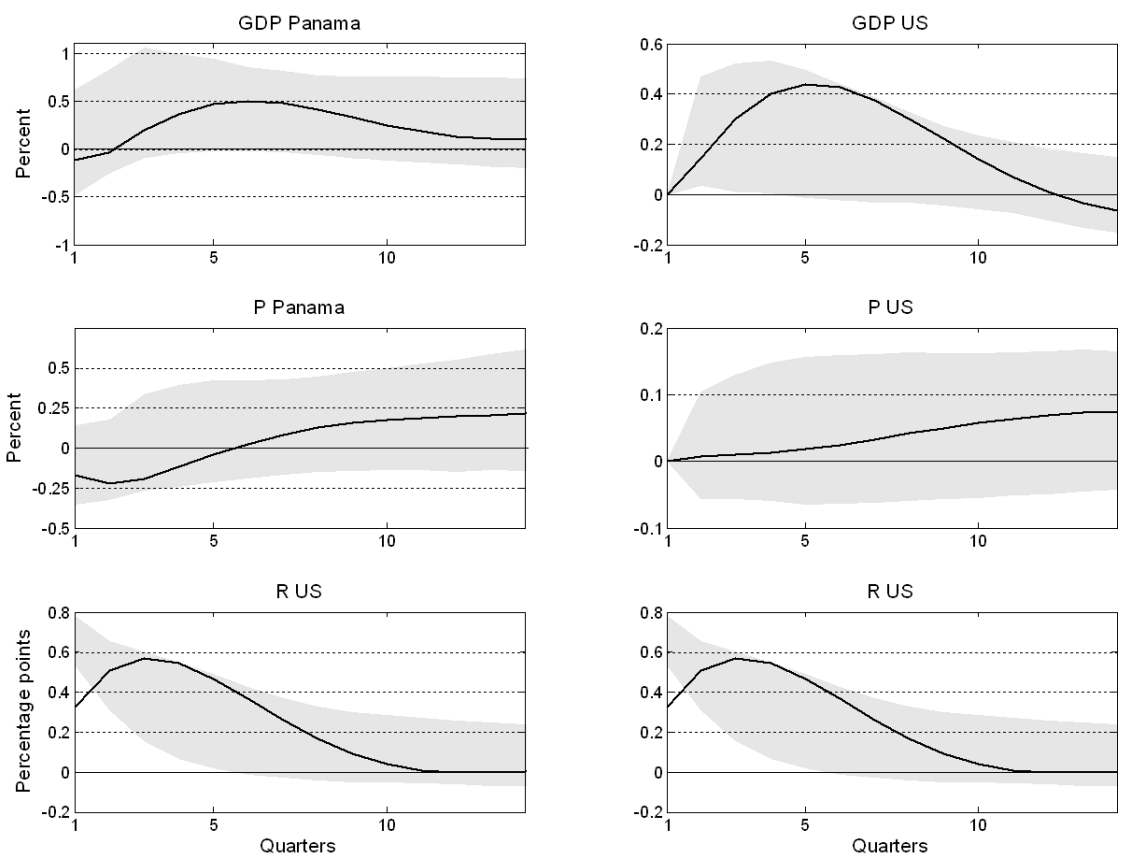

Figure 3: IRFs to a one standard deviation contractionary monetary policy shock for Panama and the US

As one can see from the figure, results largely in line with those for Ecuador and El Salvador: prices fall after a monetary tightening (although the response is never statistically different from zero), while output again does not show a significant response (the point estimate is insignificantly negative on impact, after which it becomes insignificantly positive in the third quarter after the shock).

\footnotetext{
${ }^{23}$ Faust, Swanson and Wright $(2004$, who combine high frequency futures data with the sign restriction approach to identify monetary shocks) also fail to find a clear contractionary effect of monetary shocks on US output.
} 
Summary The results for the dollarized countries thus strongly suggest that the price level falls considerably after a monetary contraction. This result is robust in that it shows up across all countries as well as across different specifications (see the Appendix). Output, on the other hand, does not show such a clear response: the results for Ecuador suggest that output is depressed (insignificantly) for about a year after a monetary contraction, El Salvador shows an output puzzle, while the (insignificant) result for Panama lies somewhere in between. Therefore, one cannot reject monetary neutrality based on these findings. In this light, the results are quite similar to those reported by Faust, Swanson and Wright (2004) and Uhlig (2005), as they also find that contractionary monetary shocks do not seem to have clear contractionary effects on real GDP.

Lessons for dollarized countries Next to the fact that Figs 1-3 tell us something about the effects of monetary policy shocks in general, they are also informative for countries that are (considering to become) dollarized. First, the results show no evidence for an important role of the working capital channel in the analyzed economies. This suggests that these countries do not have to be greatly concerned with possible stagflationary effects of monetary contractions, as for example warned for in Cavallo (1977) and Van Wijnbergen (1982).

Second, the analysis indicates that dollarized economies should be prepared for large spillovers from US monetary shocks on their price level. There is no evidence for a clear spillover effect on output, however. This might be due to the fact that prices in the client countries seem to have been quite flexible over the sample period, as a result of which these countries were close to a situation of monetary neutrality.

\section{$5 \quad$ Why are the results different?}

A key question the reader is probably left with at this stage, is why the IRFs to the same monetary policy shock, look so different for the US and the dollarized countries. A first and easy explanation is that the economies of the US on the one hand and Ecuador, El Salvador and Panama on the other, are so different, that they respond in completely opposite ways to a monetary shock. This would be the case if the working capital channel would be more important for the US, than it is for these dollarized countries. This is however hard to imagine. First, if anything, the working capital channel is probably more important for emerging economies than it is for the US, as bank financing tends to play a bigger role in the former (Van Wijnbergen, 1982: p. 134). Second, the fact that the responses of US variables are difficult to 
reconcile with any existing theory, makes them hard to believe ( $c f$. footnote 20).

A second possible reason for the differences is shock misidentification. As shown by Carlstrom, Fuerst and Paustian (2009, henceforth CFP), the "monetary policy shock" identified via the CEE-scheme may very well include non-monetary components. In particular, CFP algebraically show that in a New Keynesian model, the CEE-procedure actually identifies a weighted combination of the true innovation in monetary policy and a negative technology shock (the latter is CFP's explanation for the price puzzle). However, for all dollarized countries for which data are available, the results do not show any evidence for this type of shock confusion. ${ }^{24}$ After all, in all client economies, the identified shock (i) increases the federal funds rate, (ii) decreases the price level, and (iii) has no clear effect on output.

Apart from a contractionary monetary shock, it is hard to think of a shock that can have these three properties. In particular, CFP's negative technology shock would increase the price level, which is inconsistent with (ii). Additionally, a negative technology shock is inconsistent with (iii), as one would then expect a clear negative effect on output. On the other hand, the lack of a clear response in output to a monetary shock is in line with a standard model in which prices are rather flexible (as suggested by (ii)).

The reason for this difference may lie in the findings of the earlier cited study by Canova (2005), that non-monetary US shocks do not seem to produce significant output or price fluctuations in the client economies considered. Consequently, even if there are other disturbances present in the identified "monetary policy shock", the fact that the non-monetary components of this shock do not seem to survive the transmission process undamaged, acts like a convenient filter that leaves us more or less with what we are interested in.

If one has a strong faith in the filtering capacity of the employed setting, any attempt to identify the US monetary shock (currently done via the Choleski approach as in CEE (1999)) is not essential. After all, if non-monetary US shocks are indeed not transmitted to the dollarized countries, then the reduced form innovations to the Fed's policy rule should produce very similar responses in these countries.

And as can be verified by looking at Fig. 4, this is indeed the case: if one gives a one standard deviation, reduced form "monetary policy innovation" (which certainly is a combination of all sorts of structural shocks) to the dollarized countries, the IRFs of especially Ecuador and El Salvador are very similar to the original ones.

\footnotetext{
${ }^{24}$ If anything, the IRFs of output and prices in El Salvador and Panama look more like the response to a positive technology shock. This is, however, not only inconsistent with what is to be expected from theory ( $c f$. CFP (2009)), but also with the response of the US price level as that should fall after a positive technology shock, which it does not.
} 
For Panama, the differences between the various IRFs are a bit larger, but this is consistent with the fact that Panama's economy is more open than those of Ecuador and El Salvador and therefore less capable of filtering out non-monetary US shocks.
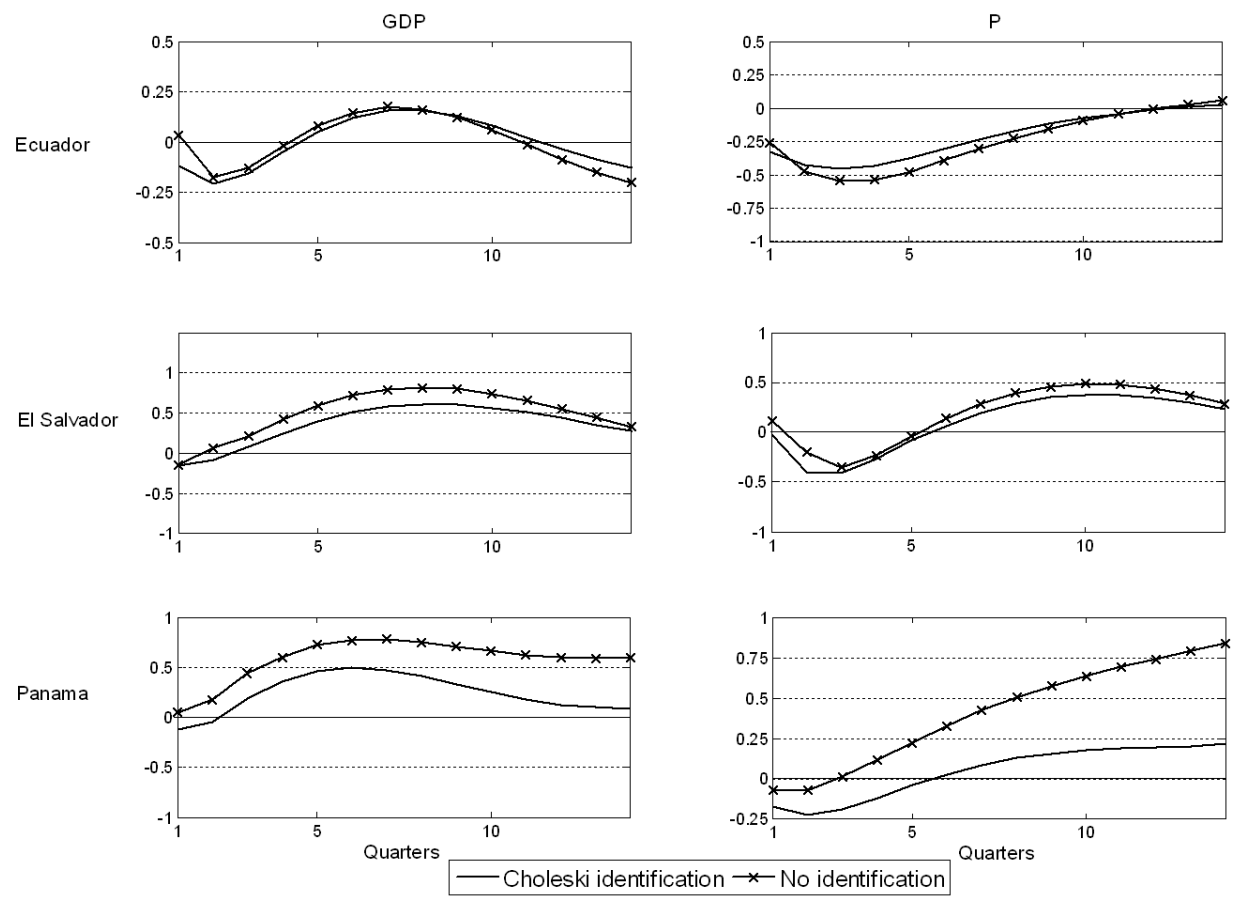

Figure 4: IRFs in dollarized countries to a "Choleski identified" US monetary policy shock and to a reduced form innovation to the Fed's reaction function

\section{Are the results informative for the US?}

To answer the question to what extent the findings for the dollarized countries considered carry over to the US economy, one should distinguish between the qualitative and quantitative messages of this paper.

Qualitatively, the results in this paper indicate that prices in dollarized countries fall after a contractionary monetary shock. This is a strong result, as many previous studies (starting with Cavallo (1977)) have emphasized the potential importance of the working capital channel for exactly these economies (in which case one would expect a price increase after a monetary contraction). Given that the price puzzle does not even emerge for these countries, it is, as said before, hard to imagine that this result would not carry over to the US (where bank financing, and hence the working capital channel, are less important). 
Potential concerns that monetary policy affects, say, the agricultural sector of the economy in the complete opposite way as it affects the service sector (whatever the reason for that may be), are unlikely to be a major issue here either: as Table 1 shows, the sectoral structure of the dollarized economies is not that different from that of the US. In all countries, the lion's share of production occurs in the service sector (with the industrial sector following at a considerable distance). ${ }^{25}$

\begin{tabular}{lllll}
\hline \hline & US & Ecuador & El Salvador & Panama \\
\hline Agriculture & $1.2 \%$ & $6.8 \%$ & $11.1 \%$ & $6.3 \%$ \\
Industry & $21.9 \%$ & $35.7 \%$ & $28.2 \%$ & $18.2 \%$ \\
Services & $76.9 \%$ & $57.6 \%$ & $60.7 \%$ & $75.5 \%$ \\
\hline \hline
\end{tabular}

Table 1: Composition of GDP by sector. Source: CIA World Factbook, 2009

Regarding the size of the effects of monetary shocks, a key issue is how degrees of price stickiness compare between the considered client, and US economies. Based on evidence from Brazil, Chile, Colombia and Mexico, Morandé and Tejada (2008) conclude that emerging economies typically exhibit more price flexibility than the US. ${ }^{26}$ If this finding carries over to the countries considered in this paper, the effects of monetary shocks on output (prices) might be a bit larger (smaller) in the US. Differences in other rigidities (such as those in the labor market), may also play a role in this respect.

\section{Conclusion and directions for further research}

In this paper, I have presented an alternative way of analyzing the effects of US monetary policy shocks. The approach exploits the fact that there exist dollarized economies that import US monetary policy just as genuine US states do. By basing inference upon the responses of variables in these client countries, one makes the procedure less vulnerable to misidentification of the monetary shock in the US block

\footnotetext{
${ }^{25}$ Data on a more disaggregated industry level (where the various countries undoubtedly do differ substantially) are not available to the best of my knowledge. Recent evidence however contradicts the hypothesis that different industries respond in opposite ways to monetary policy shocks: Boivin, Giannoni and Mihov (2009) do a factor-augmented VAR-analysis using price indices for over a hundred US industries and report that there is relatively little heterogeneity in the disaggregated responses and that only very few industries show a price puzzle (p. 367).

${ }^{26}$ Morandé and Tejada (2008) find an average price duration of approximately 1.5 months for Brazil and Mexico, while prices in Chile and Colombia tend to change once every 3 months. For the US, Bils and Klenow (2004) report a median price duration of 4.3 months.
} 
of the system, as the dollarized economies considered are only imperfectly integrated with the US economy. Consequently, non-monetary US shocks are (contrary to monetary ones) not perfectly transmitted to the client countries, and in this sense, the natural setting that this paper exploits thus works a bit like a convenient filter.

Results obtained in this way are univocal: all dollarized economies are free of the so-called price puzzle, as prices fall immediately after a monetary contraction. The working capital channel thus does not seem to have played a major role over the sample period in any of the analyzed client economies. Hereby, this paper gives support to the sign restriction procedure, as it provides empirical evidence that prices indeed fall immediately after a contractionary monetary shock (which tends to be a key identifying assumption in this procedure).

Quantitatively, the results indicate that the price effects of monetary shocks are large and show up quickly. This suggests that prices were relatively flexible in the dollarized economies over the sample period. Consistent with this, monetary policy shocks do not seem to have had a clear effect on output in the considered countries. Investigating to what extent these findings apply to the US economy itself could be a fruitful topic for further research. ${ }^{27}$

\section{Appendix}

\subsection{IRFs when estimated with SUR}

In my baseline estimation, I follow the method set out in Lastrapes (2005) and assume that the correlation between output and prices in the client countries is solely due to their joint dependence on the US variables. If one drops this assumption, $C_{i, 11}$ in equation (6) can no longer assumed to be diagonal, which implies that lagged values of $P^{D}$ now also enter the equation for $Y^{D}$ and vice versa. In that case, estimation by OLS is no longer efficient and one should estimate the system by seemingly unrelated regressions (SUR). This was done to generate the IRFs in Figure A1.

\footnotetext{
${ }^{27}$ Gobbi and Willems (2011) try to address this issue and find that this paper's conclusions indeed carry over to the US economy: when they identify US monetary shocks by putting sign restrictions on prices in the client countries only (thus leaving the responses of US output and prices unrestricted), they find that US prices tend to fall as well after a monetary contraction suggesting that the working capital channel does not play a significant role in the US either. In line with this paper's results for the dollarized countries, US GDP also does not show a clear response in their study.
} 

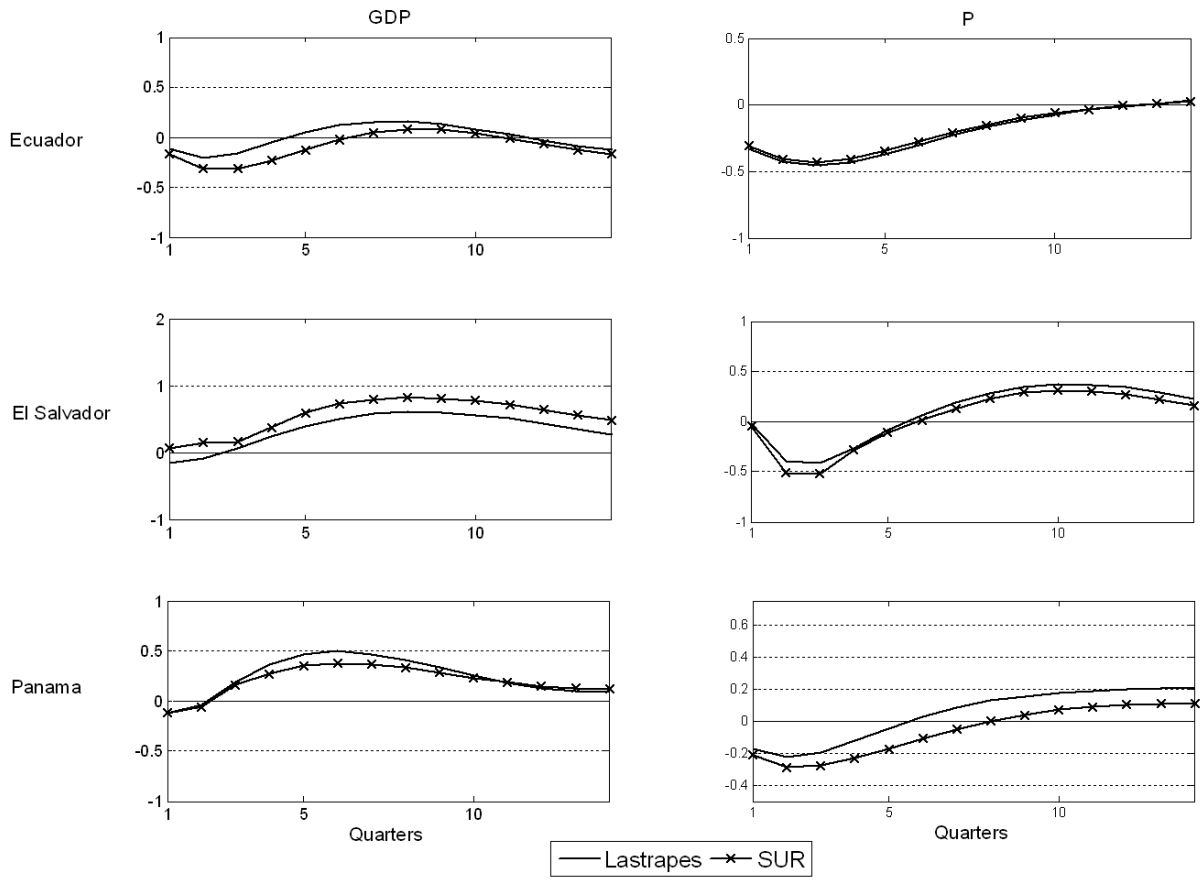

Figure A1: IRFs estimated via Lastrapes (2005) and via SUR

As the figure shows, results are hardly affected by this so the assumption made in Lastrapes (2005) seems to be a reasonable one for the case currently at hand. (The IRFs of the US variables are not reported in Figure A1, as they are not affected by this robustness check at all.)

\subsection{IRFs without a time trend}

Figure A2 shows the relevant IRFs if one estimates the VAR without a time trend. As can be seen in the figure, the results are again robust to this. This holds even more so for the US variables (not reported here). 

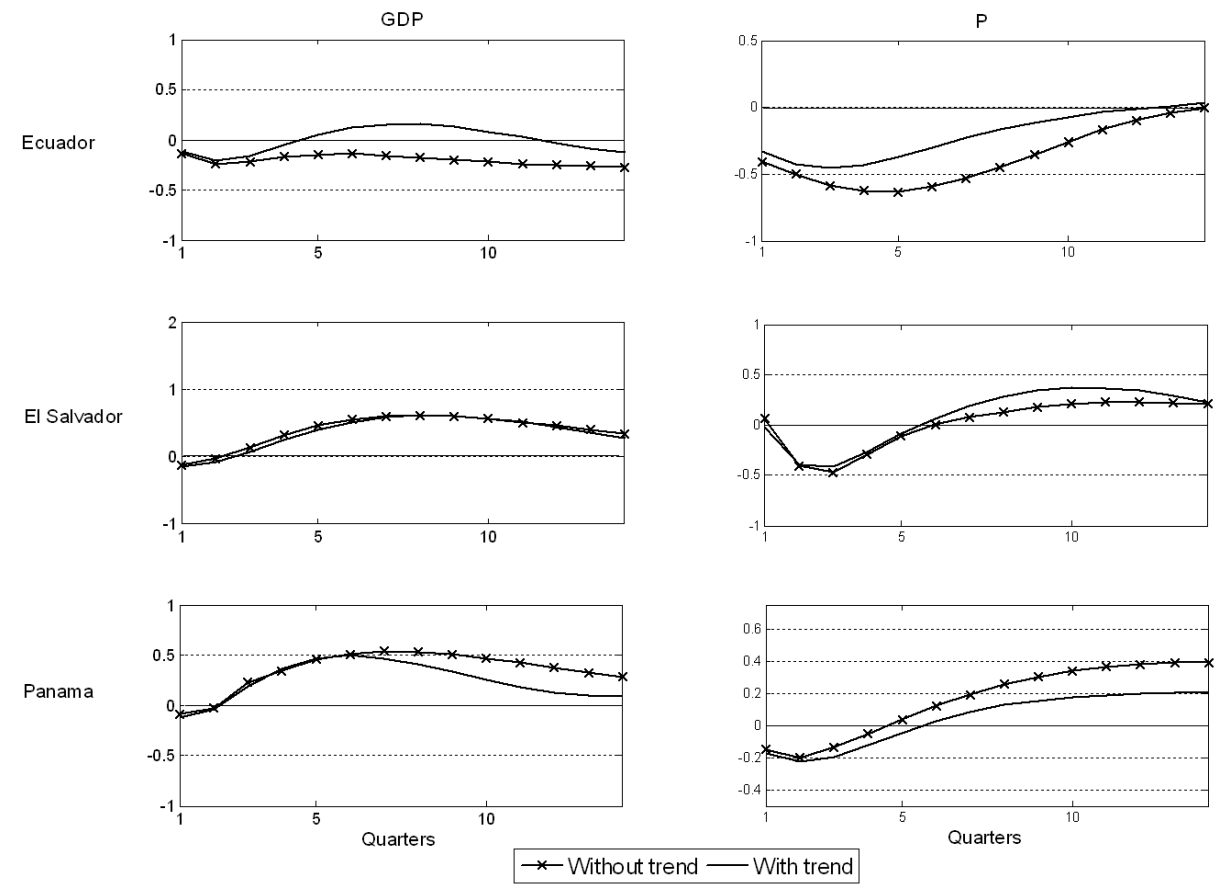

Figure A2: IRFs with and without a time trend

\subsection{IRFs when M2 is included}

As shown in Figures A3-A5, the results are also robust to including M2 in the US block of the system. Here, I also display the responses of US variables to show that including M2 does not solve the price puzzle and that there is no "liquidity puzzle" present in my analysis (that is, consistent with theory, an increase in the federal funds rate is associated with a decrease in M2). 

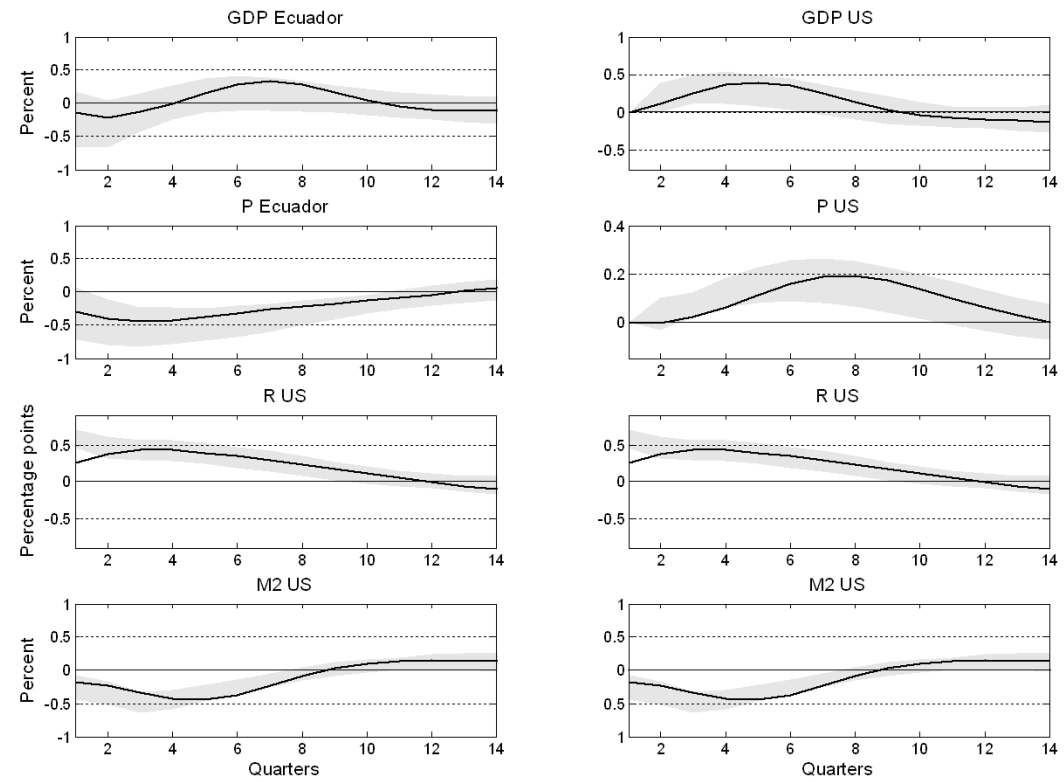

Figure A3: IRFs for Ecuador and the US when M2 is included
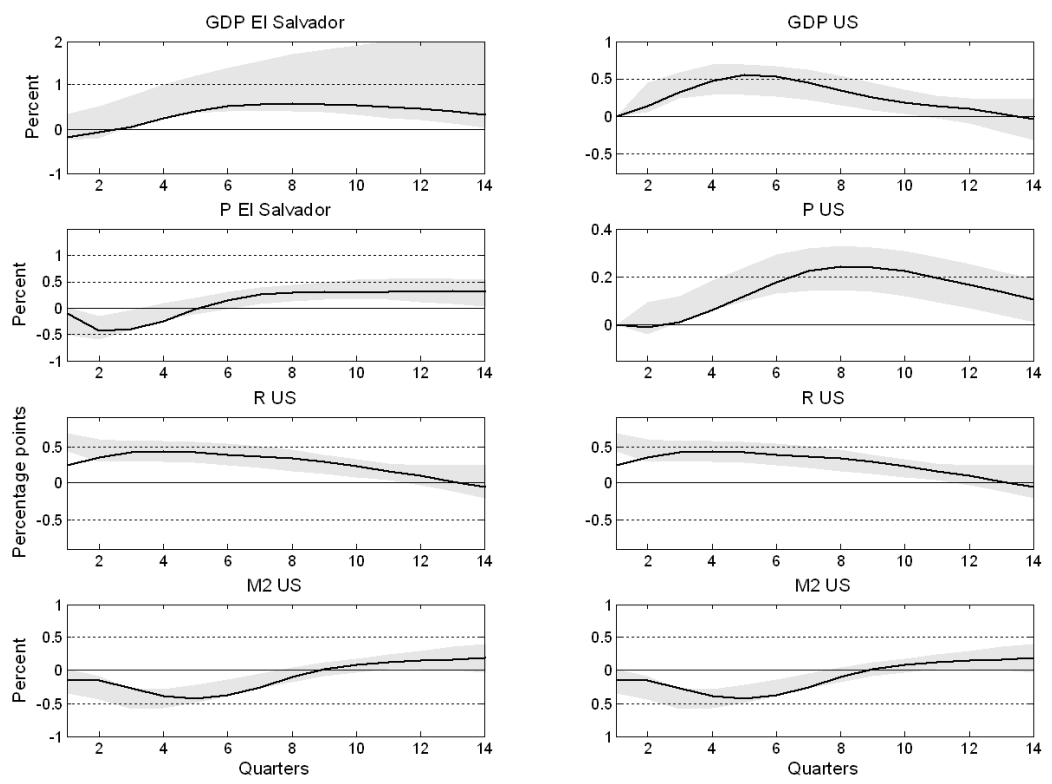

Figure A4: IRFs for El Salvador and the US when M2 is included 

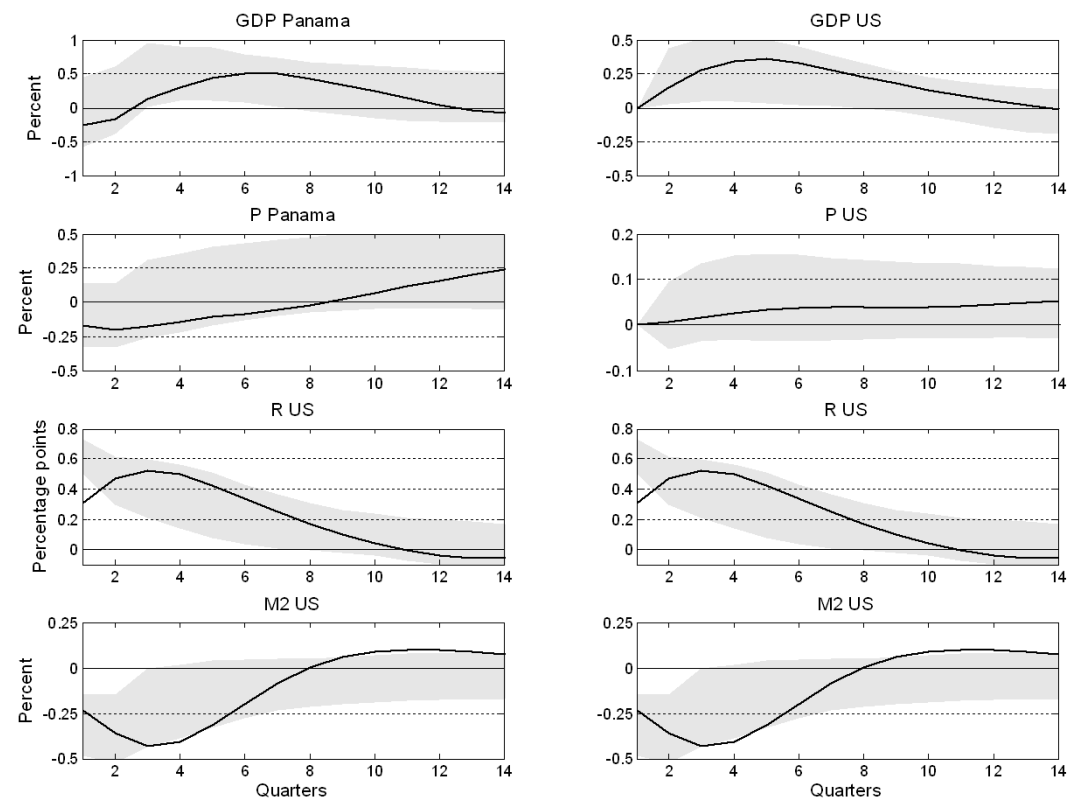

Figure A5: IRFs for Panama and the US when M2 is included

\subsection{IRFs when an index of commodity prices is included}

Finally, Figures A6-A8 show that conclusions are also not affected by the addition of the IMF's commodity price index to the VAR. Moreover, one can see from these figures that the inclusion of commodity prices does not solve the US price puzzle for the samples currently at hand (which is in line with the findings of Hanson (2004)). 

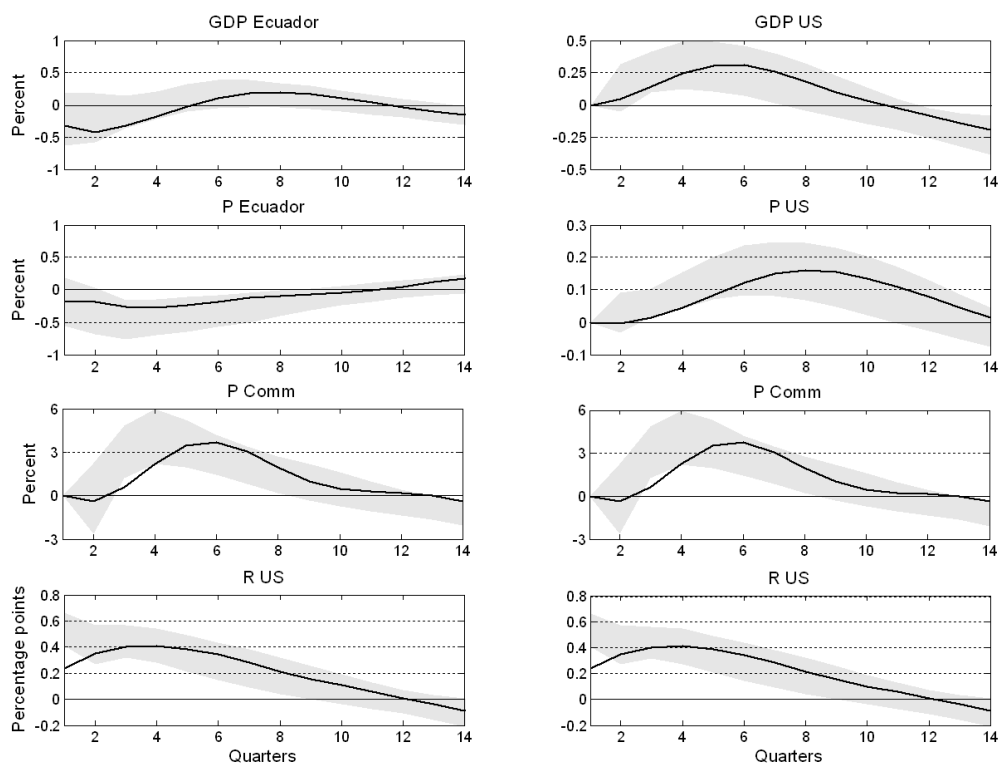

Figure A6: IRFs for Ecuador and the US when the IMF's commodity price index is included
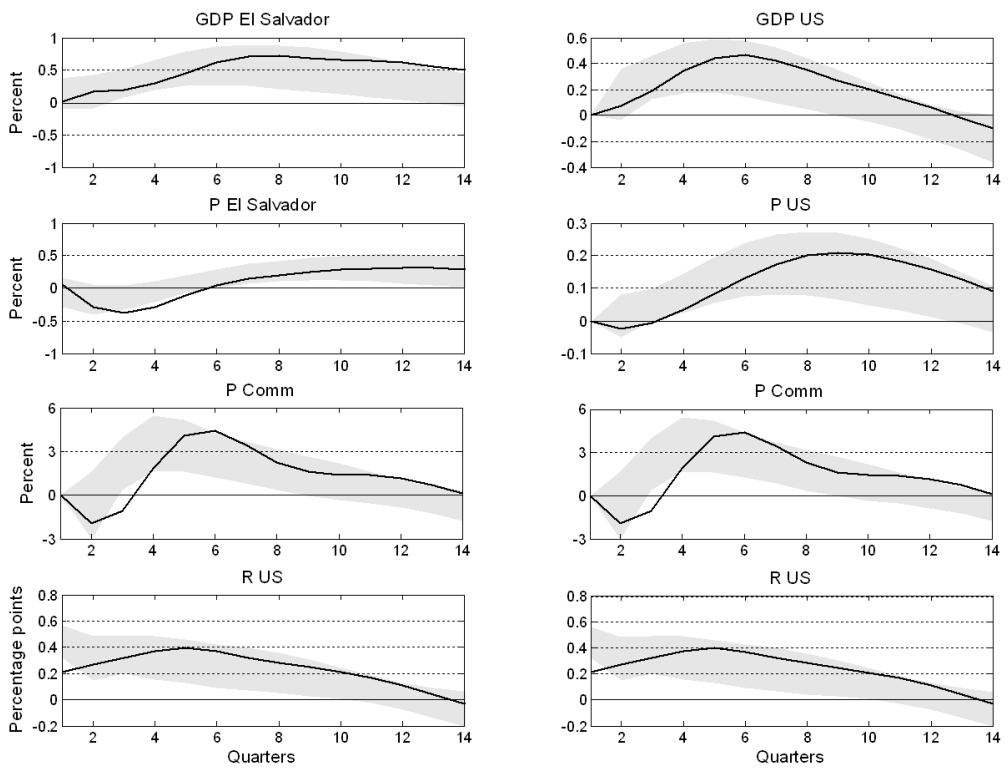

Figure A7: IRFs for El Salvador and the US when the IMF's commodity price index is included 

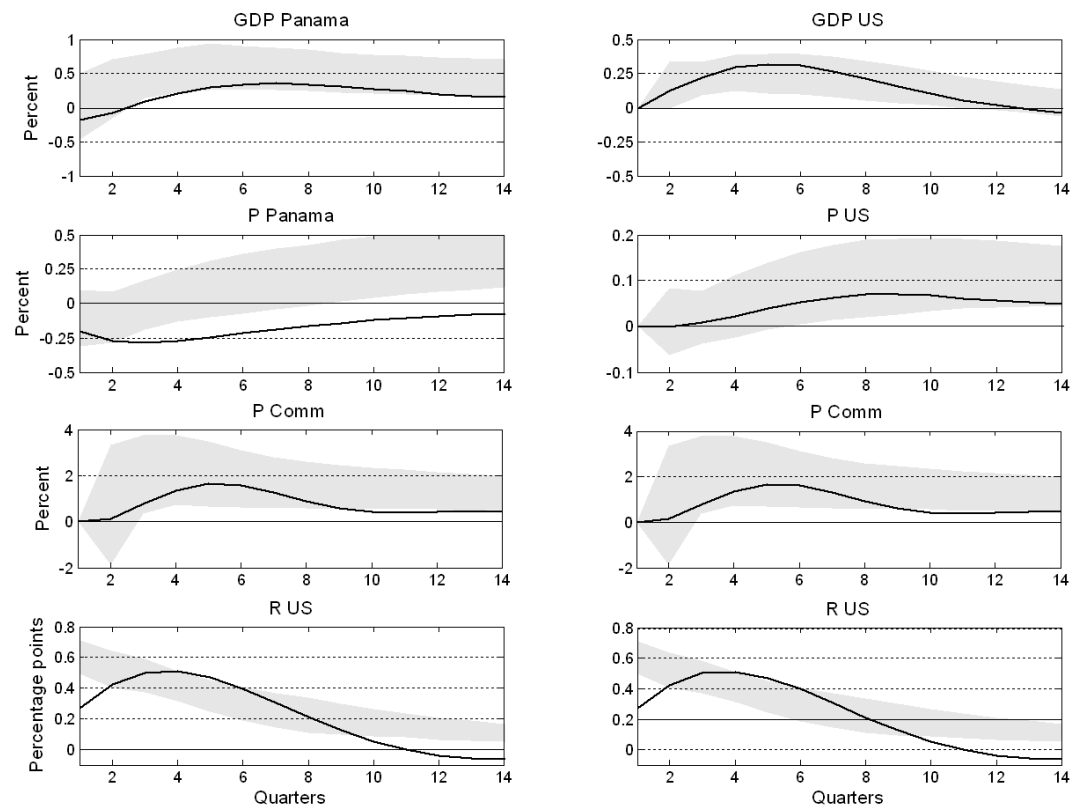

Figure A8: IRFs for Panama and the US when the IMF's commodity price index is included

\section{References}

Alesina, A., Barro, R.J. and S. Tenreyro (2002), "Optimal Currency Areas", in: M. Gertler and K. Rogoff (eds.), NBER Macroeconomics Annual, Cambridge, MA: MIT Press, pp. 301-345.

Barth, M.J. and V.A. Ramey (2001), "The Cost Channel of Monetary Transmission", in: B.S. Bernanke and K. Rogoff (eds.), NBER Macroeconomics Annual, Cambridge, MA: MIT Press, pp. 199-240.

Beckerman, P. (2001), "Dollarization and Semi-Dollarization in Ecuador", World Bank Policy Research Working Paper No. 2643.

Bernanke, B.S. and A.S. Blinder (1992), "The Federal Funds Rate and the Channels of Monetary Transmission", American Economic Review, 82 (4), pp. 901-921.

Bernanke, B.S. and I. Mihov (1998), "Measuring Monetary Policy", Quarterly Journal of Economics, 113 (3), pp. 869-902.

Bils, M. and P.J. Klenow (2004), "Some Evidence on the Importance of Sticky Prices", Journal of Political Economy, 112 (5), pp. 947-985.

Boivin, J., M. Giannoni and I. Mihov (2009), "Sticky Prices and Monetary Policy: 
Evidence from Disaggregated US Data", American Economic Review, 99 (1), pp. 350-384.

Canova, F. (2005), "The Transmission of US Shocks to Latin America", Journal of Applied Econometrics, 20 (2), pp. 229-251.

Canova, F. and J. Pina (2005), "What VAR Tell us about DSGE Models", in: C. Diebolt and C. Krystou (eds.), New Trends in Macroeconomics, New York, NY: Springer-Verlag.

Carlstrom, C.T., T.S. Fuerst and M. Paustian (2009), "Monetary Policy Shocks, Choleski Identification, and DNK Models", Journal of Monetary Economics, 56 (7), pp. 1014-1021.

Cavallo, D. (1977), "Stagflationary Effects of Monetarist Stabilization Policies", $\mathrm{PhD}$ Thesis (Harvard University, Cambridge, MA.).

Christiano, L.J., M. Eichenbaum and C.L. Evans (1999), "Monetary Policy Shocks: What Have We Learned and to What End?", in: J. Taylor and M. Woodford (eds.), Handbook of Macroeconomics, Vol. 1A, Amsterdam, North-Holland: Elsevier, pp. 65-148.

Christiano, L.J., M. Eichenbaum and C.L. Evans (2005), "Nominal Rigidities and the Dynamic Effects of a Shock to Monetary Policy", Journal of Political Economy, 113 (1), pp. 1-45.

Cushman, D.O. and T. Zha (1997), "Identifying Monetary Policy in a Small Open Economy under Flexible Exchange Rates", Journal of Monetary Economics, 39 (3), pp. 433-448.

Dornbusch, R. (1976), "Expectations and Exchange Rate Dynamics", Journal of Political Economy, 84 (6), pp. 1161-1176.

Faust, J., E.T. Swanson and J.H. Wright (2004), "Identifying VARS Based on High Frequency Futures Data", Journal of Monetary Economics, 51 (6), pp. 11071131.

Gabaix, X. (forthcoming), "The Granular Origins of Economic Fluctuations", Econometrica.

Gobbi, A. and T. Willems (2011), "Identifying US Monetary Policy Shocks Through Sign Restrictions in Dollarized Countries", mimeo, University of Amsterdam.

Hamilton, J.D. (1994), Time Series Analysis, Princeton, NJ: Princeton University Press.

Hanson, M.S. (2004), "The 'Price Puzzle' Reconsidered", Journal of Monetary Economics, 51 (7), pp. 1385-1413.

Lastrapes, W.D. (2005), "Estimating and Identifying Vector Autoregressions Under Diagonality and Block Exogeneity Restrictions", Economics Letters, 87 (1), pp. 75-81. 
Lindenberg, N. and F. Westermann (2010), "How Strong is the Case of Dollarization in Central America? An Empirical Analysis of Business Cycles, Credit Market Imperfections and the Exchange Rate", mimeo, University of Osnabrück.

Morandé, F. and M. Tejada (2008), "Price Stickiness in Emerging Economies: Empirical Evidence for Four Latin-American Countries", Universidad de Chile, Documentos de Trabajo No. 286.

Ravenna, F. and C.E. Walsh (2006), "Optimal Monetary Policy with the Cost Channel", Journal of Monetary Economics, 53 (2), pp. 199-216.

Sachs, J.D. and A. Warner (1995), "Economic Reform and the Process of Global Integration", Brookings Papers on Economic Activity, 1, pp. 1-118.

Sims, C.A. (1986), "Are Forecasting Models Usable for Policy Analysis?", Federal Reserve Bank of Minneapolis Quarterly Review, 10 (1), pp. 2-16.

Sims, C.A. (1992), "Interpreting the Macroeconomic Time Series Facts", European Economic Review, 36 (5), pp. 975-1011.

Sims, C.A. and T. Zha (2006), "Does Monetary Policy Generate Recessions?", Macroeconomic Dynamics, 10 (2), pp. 231-272.

Uhlig, H. (2005), "What Are the Effects of Monetary Policy on Output? Results from an Agnostic Identification Procedure", Journal of Monetary Economics, 52 (2), pp. 381-419.

Van Wijnbergen, S. (1982), "Stagflationary Effects of Monetary Stabilization Policies", Journal of Development Economics, 10 (2), pp. 133-169.

Van Wijnbergen, S. (1983), "Interest Rate Management in LDCs", Journal of Monetary Economics, 12 (3), pp. 433-452. 